\title{
The 'common vole' in Svalbard identified as Microtus epiroticus by chromosome analysis
}

\author{
KARL FREDGA, MAARIT JAAROLA, ROLF ANKER IMS, HARALD STEEN AND NIGEL G. YOCCOZ
}

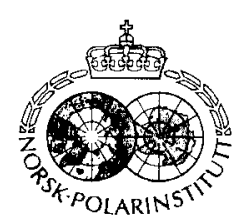

\begin{abstract}
Fredga, K., Jaarola, M., Ims, R. A., Steen, H. \& Yoccoz, N. G. 1990: The 'common vole' in Svalbard identified as Microtus epiroticus by chromosome analysis. Polar Research 8, 283-290.

The chromosomes were studied in six individuals from a population of Microtus from Grumantbyen, Svalbard, and in six Microtus arvalis (Pallas 1778) from Lauwersee, Holland. It was shown that the voles from Svalbard did not belong, as earlier supposed, to the species $M$. arvalis $(2 \mathrm{n}=46)$ but to $M$. epiroticus (Ondrias, 1966) $(2 n=54)$. We suggest that the Svalbard voles were introduced by man between 1920 and 1960 together with hay on Russian ships from the vicinity of Leningrad, USSR.
\end{abstract}

Karl Fredga and Maarit Jaarola, Department of Genetics, Uppsala University, P.O. Box 7003, S-750 07 Uppsala, Sweden; Rolf Anker Ims and Harald Steen, Department of Biology, Division of Zoology. University of Oslo, P.O. Box 1050 Blindern, N-0316 Oslo 3. Norway; Nigel G. Yoccoz. Department of Biology, Division of Zoology, University of Oslo, P.O. Box 1050 Blindern, N-0316 Oslo 3, Norway, or: Laboratoire de Biometrie, Université Claude Bernard Lyon 1, 69622 Villeurbanne Cedex, France; February 1990 (revised July 1990).

In 1960 a member of the Finnish zoological expedition to Svalbard found the first vole in Svalbard at Longyearbyen. In 1964 and 1965 voles were abundant in the Longyearbyen village and district and several specimens were collected (Nyholm 1966). In 1975 voles were trapped at Hotellneset, Longyearbyen, and in 1976 at Fuglefjellet, Grumantbyen, W Adventfjorden, by Alendal (1977). The voles collected in the 1960s and 1970s were identified as Microtus arvalis (Pallas 1778) on morphological grounds. A more recent report describes voles collected at Coles Bay and Barentsburg as $M$. arvalis (Bolshakov \& Shubnikova 1988). The present study is part of a comparative ecological investigation aimed at revealing which circumstances make it possible for a southern vole species to establish itself in arctic conditions. In order to find a relevant reference population it was important to find out, if possible, the origin of the ancestors.

Microtus must have been brought to Svalbard by man and according to Alendal (1977), the voles might have been introduced by whale and walrus hunters from Holland in the 17th or 18th century. This conclusion was based on the identification of the specimens captured in Svalbard as Microtus arvalis.

In 1972 a new Microtus species was described by Meyer et al. It was called $M$. subarvalis, but since this name is an absolute homonym of a fossil species, Microtus subarvalis Heller 1933, the name was changed to $M$. epiroticus Ondrias 1966 (see Honacki et al. 1982).* It is a sibling

*Recently, the name Microtus rossiaemeridionalis Ognev 1924 was applied to this species (Malygin 1983: Malygin \& Yatsenko 1986). Fifteen specimens of the 'common vole' were collected in the type locality (Aninsk region, Voronej district) of the taxon $M$. arvalis rossiaemeridionalis Ognev 1924. All fiftcen had $2 \mathrm{n}=54$ and since, according to Malygin \& Yatsenko (1986), M. arvalis $(2 n=46)$ does not exist in this area they conclude that the animals described by Ognev also must have had 54 chromosomes. Consequently, the sibling species with 54 chromosomes should be called $M$. rossiaemeridionalis Ognev 1924 and not $M$. epiroticus Ondrias 1966. However, we are not willing to accept their conclusion for the following reasons:

1. We can not know which taxon Ognev described in 1924 since the two sibling species of 'common voles' can not be distinguished by their external morphology. He did not study the characters that distinguish the two (chromosomes. blood proteins or sperm).

2. $M$. arvalis 'arvalis' and $M$. arvalis 'obscurus' occur west and east of Voronej, respectively. Is it possible to exclude the present occurrence of either of these at the type locality of $M$. a. rossiaemeridionalis? Only 15 specimens were investigated. Also, the distribution of the two sibling species may have changed since 1924 (?) when the holotypc of rossiaemeridionalis was collected.

3. We recommend that this question be considered by the International Commission on Zoological Nomenclature. According to Article 80, Status of case under consideration (a) (International Code of Zoological Nomenclature 1985), existing usage is to be maintained until a ruling of the Commission is published. Presently, the two authoritative taxonomic references (Niethammer \& Krapp 1982; Honacki et al. 1982) use the name M. epiroticus Ondrias 1966.

For these reasons we prefer to use the name $M$. epiroticus in the present article. 


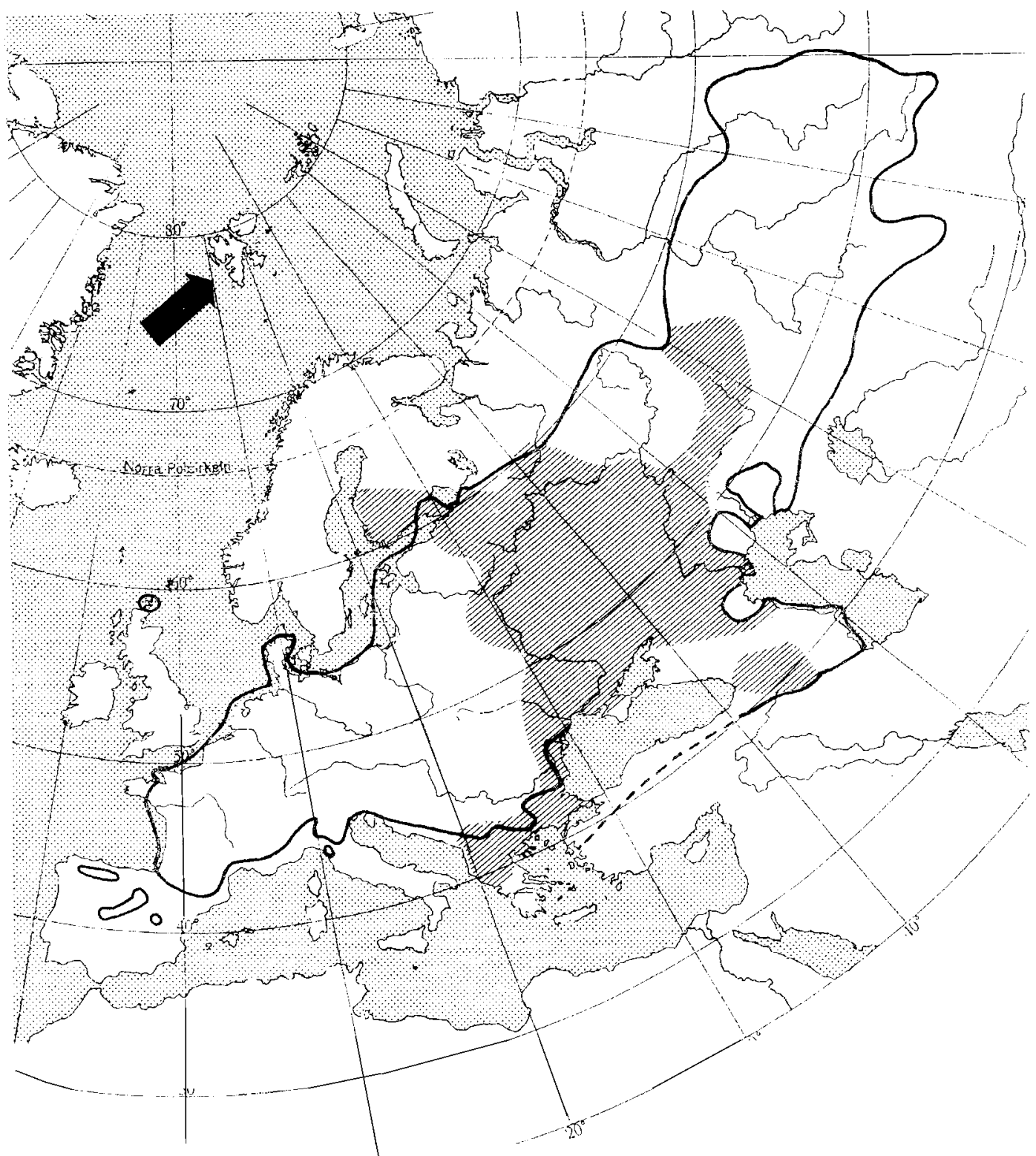

Fig. 1. Distribution of M. arvalis (solid line) and M. epiroticus (shadowed) in Europe and western USSR (based on Matygin \& Orlov 1974; Král ct al. 1980; Niethammer \& Krapp 1982; Vorontsov et al. 1984).

species of $M$. arvalis, and is found within the central part of the vast distribution area of $M$. arvalis (Fig. 1). The new species cannot be distinguished from $M$. arvalis by external morphology, but the two species have characteristic karyotypes: $M$. epiroticus has $2 \mathrm{n}=54$ and $M$. arvalis has $2 \mathrm{n}=46$. There is also a difference between the two species in the size and shape of the spermatozoa and with regard to several proteins (Mejer et al. 1972, 1973; Sakiyan et al. 1984).

Since both $M$. arvalis and $M$. epiroticus potentially could have been introduced from Russia with supply ships to some of the permanent Russian settlements in Svalbard, it was important to study the chromosomes of the Svalbard voles. 
Furthermore, the comparison of the chromosomes and the mitochondrial DNA of voles from Svalbard with voles from Holland and other parts of northern Europe might solve the problem of origin and perhaps also tell something about the number of specimens introduced.

We here show that the Microtus, belonging to a viable population living in natural habitats in the surroundings of Grumantbyen, Isfjorden, are $M$. epiroticus and not $M$. arvalis as believed earlier (Alendal 1977).

\section{Material and methods}

During a two-week period in late August 1989, three of us visited localities in the Isfjorden area where Microtus either had been captured or 'seen' according to Alendal (1977). Coles Bay and some other localities were also checked (Fig. 2).

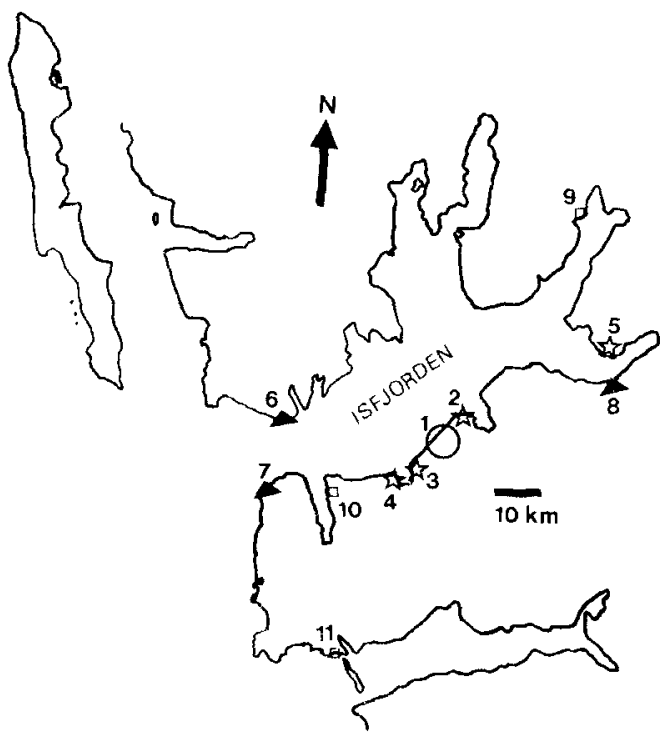

Fig. 2. Map of the Isfjorden area. Circle: Voles caught during the present study. Stars: Voles reported to be present by Nyholm (1966), Alendal (1977) or Bolshakov \& Shubnikova (1988), but not found by us examining the localities in August 1989. Triangles: Localities with no carlier reports about vole occurrence, but examined by us in August 1989 with negative results. Squares: Localities prevjously reported to contain voles (Alendal 1977; Bolshakov \& Shubnikova 1988) but not cxamined by us. $1=$ Grumantbyen, 2 = Longyearbyen, $3=$ Coles Bay, $4=$ Kapp Laila, 5 = Bjonahavna, Tempelfjellet, $6=$ Alkhornet, $7=$ Kapp Linné, $8=$ Sassendalen, $9=$ Pyramiden, $10=$ Barentsburg, $11=$ Bellsund
Each locality was first examined for signs of small rodents (grazing, runways or faeces) in grassy vegetation. Such signs of Microtus activity are conspicuous even at low densities. At places where signs were found multiple-capture livetraps (type: Ugglan) were set.

Only the area between Bjørndalen, $2 \mathrm{~km} \mathrm{~W}$ Longyearbyen, and Coles Bay (Fig. 2) was found to be inhabited by Microtus. Signs of Microtusactivity were, however, most pronounced in the grassy slopes under Fuglefjella and the animals seemed to prefer places on peat soil with lush vegetation of grass and herbs, interspersed with patches of boulders. Generally, these preferred areas were on stable well-drained ground.

Approximately 100 live-traps were set for $2 \frac{1}{2}$ days in the surroundings of Grumantbyen. A total of 46 individuals were caught, indicating a dense population. The animals were brought alive to the Department of Biology, University of Oslo, where a breeding colony was established.

Fifty $M$. arvalis were live trapped in October 1989 at Lauwersee, NE Holland. All specimens were brought alive to the Department of Biology, University of Oslo, where a breeding colony was established.

Six of the voles from Svalbard and six from Holland, 4 males and 2 females of each population, were karyotyped. Chromosome preparations were made from bone marrow by the direct method of Fredga (1987). For G- and C-banding the techniques of Wang \& Fedoroff (1972) and Sumner (1972) were used, respectively.

\section{Results}

\section{M. epiroticus}

The six voles studied from Svalbard had identical autosomal karyotypes and males were $X Y$, females XX. The chromosome number was $2 \mathrm{n}=$ 54 and all chromosomes but the smallest pair of autosomes were telocentric (Fig. 3A). The $\mathrm{X}$ chromosome was the largest of the complement and the $\mathrm{Y}$ the next largest, but close in size to the largest autosome. This autosome was the only telocentric that could be identified without Gbanding. The rest of the single-armed autosomes decreased continuously in size. A G-banded karyotype is shown in Fig. 3B. After C-staining, all autosomes showed centromeric C-bands (Fig. $3 \mathrm{C}$ ). The distal half of the $\mathrm{X}$ stained as a positive C-block and the entire $\mathrm{Y}$ appeared dark after 


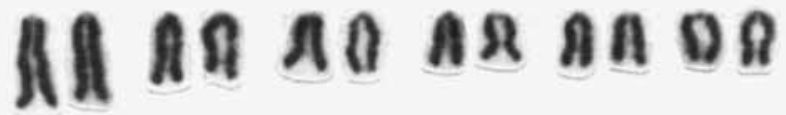

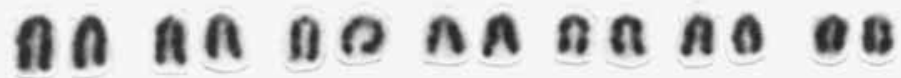

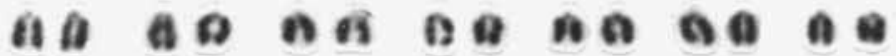

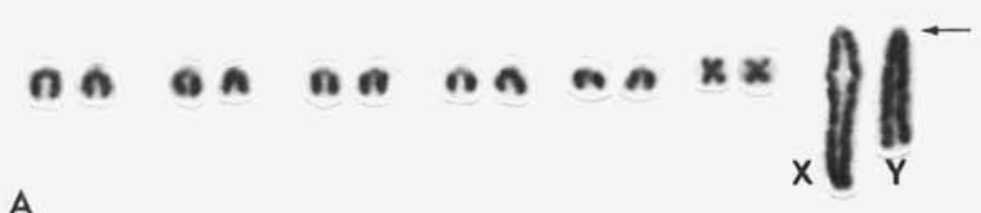

A

\section{HII $11 \mathrm{H} \| \mathrm{H}$ औी}

If 14 a 3 it 18 is

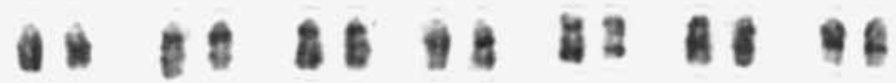

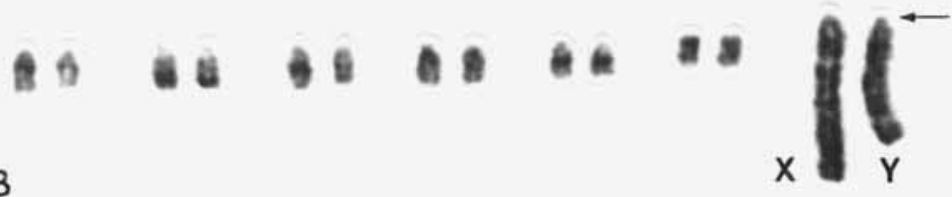

B

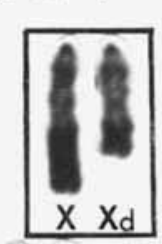

if 10 : 180 iी 18

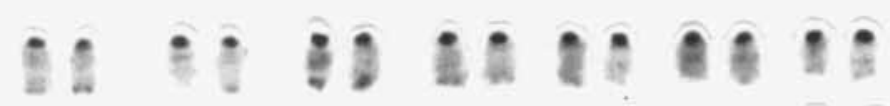

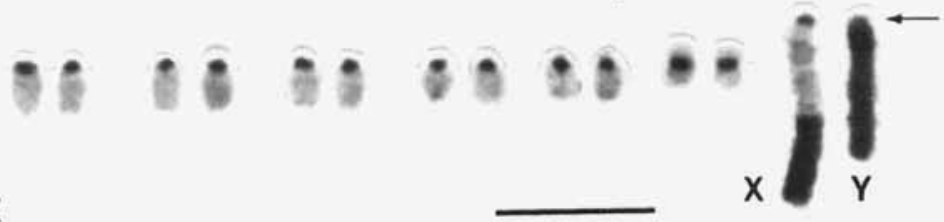

Fig. 3. Karyotypes of male Microtus epiroticus from Grumantbyen, Svalbard. A) unbanded, B) G-banded, C) C-banded. Boxed: sex chromosomes from a female with one normal and one deleted $X$ chromosome (Xd). Arrows indicate the position of the centromeres in the sex chromosomes. Preparations from bone marrow. Bar $=10 \mu \mathrm{m}$. Same magnification in A, B and C. 


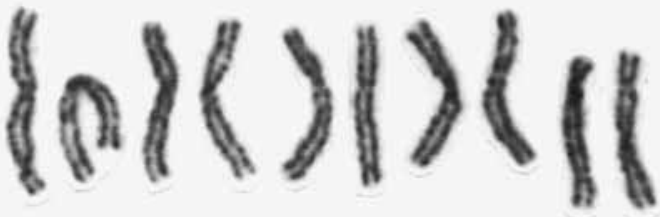

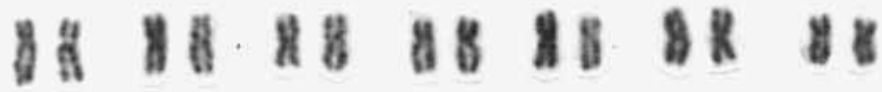

K女 ถ⿻

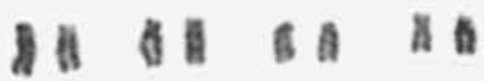

A

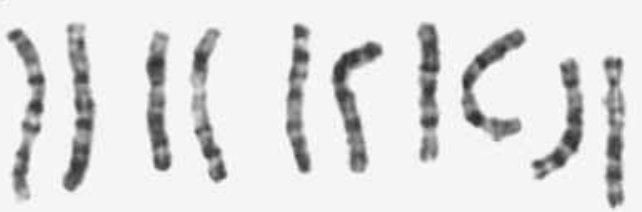

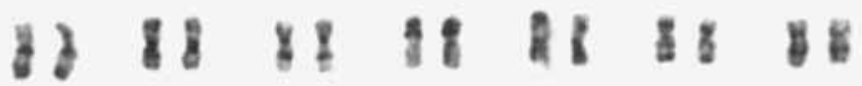

1888 is 883811

it 14 a 2 a

B
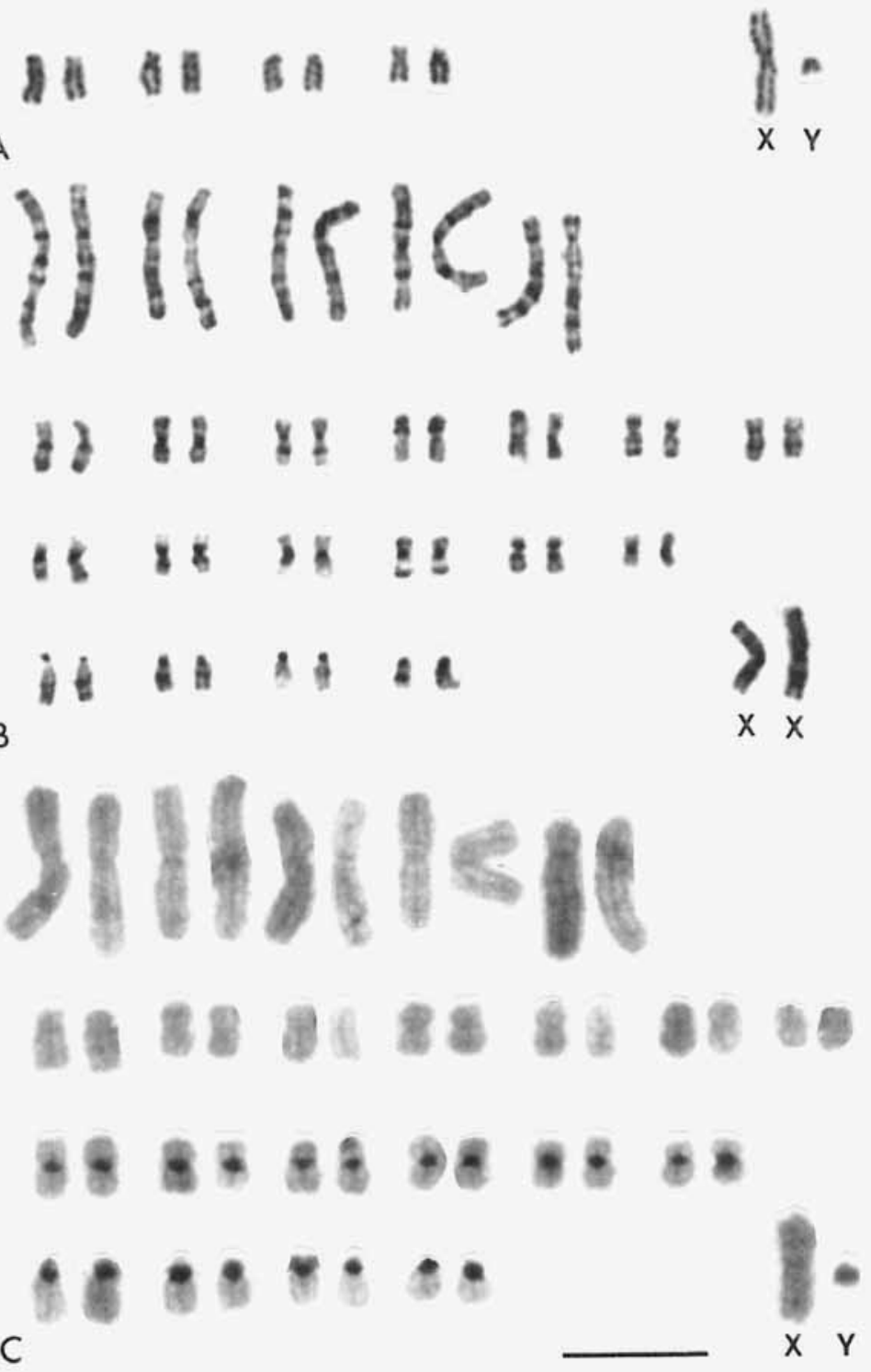

Fig. 4. Karyotypes of Microtus arvalis from Lauwersee, Holland. A) male, unbanded, B) female, G-banded, C) male, C-banded. Preparations from bone marrow. Bar $=10 \mu \mathrm{m}$. Same magnification in A, B and C. 
C-staining. One of the females studied had one normal and one deleted $\mathrm{X}$; a little more than half of the heterochromatic distal part was missing (Fig. 3C).

The karyotypes of the voles from Svalbard are in perfect agreement with those of $M$. epiroticus from Finland (Fredga et al. unpublished) and from different parts of the USSR (Vorontsov et al. 1984; Mejer et al. 1985).

\section{M. arvalis}

The six voles from Holland had identical karyotypes (males $\mathrm{XY}$, females $\mathrm{XX}$ ). The chromosome number was $2 n=46$. The autosomes may be divided into two size groups: 5 large and 17 small pairs. All the large chromosomes and 13 of the small were bi-armed. Four of the small chromosomes were acrocentric. The $\mathrm{X}$ chromosome was of intermediate size and metacentric, the $Y$ was the smallest of the complement and acrocentric (Fig. 4A).

A G-banded karyotype is shown in Fig. 4B. After C-staining, centromeric blocks of heterochromatin were present in 10 of the small pairs, 6 bi-armed and 4 acrocentric (Fig. 4C). The NF value was 84 (female).

Different populations of $M$. arvalis may be distinguished by their karyotypes (Král \& Lyapunova 1975; Zima \& Král 1984). They all have $2 n=46$ and 5 large, bi-armed chromosomes, but the number of small single-armed pairs varies, as well as the number of chromosomes with centromeric C-blocks. The karyotype of voles from this Dutch population is similar (but not identical) to that of voles from Osnabrück in Germany (Gamperl 1982). They both have 10 pairs with C-blocks and no acrocentric without. However, the number of acrocentric pairs in the Dutch population is 4 compared to 3 in the German one.

\section{Discussion}

The present chromosome study has shown that the voles collected in 1989 at Fuglefjella, Grumantbyen, belong to the species M. epiroticus. Five individuals caught in 1976 in the same area by Alendal (1977) were identified as M. arvalis, according to guidelines from literature that did not distinguish arvalis from epiroticus. We were not able to find voles anywhere else, although attempts were made at another seven sites (Fig. 2). This means that we cannot exclude the possibility that the voles caught by earlier investigators at Longyearbyen and its vicinities (Nyholm 1966; Alendal 1977), Coles Bay and Barentsburg (Bolshakov \& Shubnikova 1988) really were $M$. arvalis. Bolshakov \& Shubnikova (1988) pointed out, however, that Microtus in Svalbard needs to be karyotyped to confirm the identification of the species.

The distribution of $M$. arvalis and $M$. epiroticus is shown in Fig. 1. M. arvalis is present in western Europe, from the Atlantic coast and eastwards to about longitude $90^{\circ} \mathrm{E}$ in western Siberia. $M$. epiroticus has a more limited distribution in the approximate middle third of this vast area. In Europe $M$. epiroticus has its northernmost populations in Finland and the southernmost on the Balkan peninsula. These are also the two westernmost areas of its distribution. The type locality of $M$. epiroticus is in the Epiros mountains in northwestern Greece (Ruzic et al. 1975).

The two species exist sympatrically in many areas but appear to occupy different habitats in the breeding season. In the winter $M$. epiroticus seems to have the habit of living in association with human settlements, in hay barns etc. In the vicinity of Saratov on the east bank of the Volga River both species were caught in two haystacks in early spring (Belanin et al. 1973, quoted by Král et al. 1980). In both haystacks $M$. epiroticus was by far the most common species, the proportions of epiroticus and arvalis being 38:3 and $56: 2$, respectively. However, the exact ecological requirements of either species and the differences between the species have not yet been fully elucidated (Král et al. 1980).

The close association of the Svalbard voles to human buildings has been pointed out by several authors (Nyholm 1966; Alendal 1977; Bolshakov \& Shubnikova 1988). The apparent association of $M$. epiroticus with humans may have been important during the species' colonization and establishment in Svalbard. However, it is clear that the highly viable population in the Fuglefjella area occurs in natural habitats independent of human settlements.

Svalbard is located $657 \mathrm{~km}$ north of Nordkapp, midway between Norway and the North Pole, and has never been connected by a landbridge with Fennoscandia or any other part of the Eurasian continent. Voles cannot possibly have survived a fortuitous transport on ice or on a 
floating $\log$ because of the long distances involved. Thus, the voles must have been brought to Svalbard by man. (We also exclude the possibility that voles were introduced secretly to Svalbard by scientists as part of an ecological experiment.)

Both arvalis and epiroticus exist in the Leningrad region (Pavlovsk, Volosovo and Volchov districts), but in the areas closest to the coast (Leningrad and the Lomonosov district) only epiroticus was found (Mejer et al. 1972; Malygin \& Orlov 1974; Král et al. 1980). However, the recent discovery of $M$. arvalis in southeastern Finland (Fredga et al. unpublished) indicates that both species may occur sympatrically along the easternmost coasts of the Gulf of Finland. However, M. epiroticus is by far the most common species in Finland and adjacent parts of the USSR.

Hence, Finiand, western USSR and Balkan are the only areas where $M$. epiroticus exists near water and harbours. We are not aware of any transportations from the eastern Mediterranean (Yugoslavia or Greece) or from the Black Sea (USSR, Rumania or Bulgaria) to Svalbard. Finland has not been involved in any industrial or agricultural activities in Svalbard. Thus, we find it unlikely that the voles in Svalbard originate from the Balkan Peninsula or Finland but from the western parts of the USSR, bordering the Gulf of Finland.

The Russians have exploited coal mines in Grumantbyen since 1920 (Hoel 1966) and at Coles Bay since 1938 (Bolshakov \& Shubnikova 1988). Horses were used for transportation and hay must have been brought there for their winter survival. We conclude that the voles were introduced together with hay by Russian ships from Leningrad (or nearby harbours) in the period 1920-1960, and thus originate from the vicinity of Leningrad. Prof. Charles Elton visited Svalbard in 1921, 1923 and 1924 as a member of the Oxford expeditions to Svalbard. 'I feel certain they [the voles] were not introduced by 1924 the last time I went there! I would have been told' (Charles Elton, in a letter to K.F.).

Further studies of DNA may tell us whether voles were introduced to Svalbard more than once, and may also support the hypothesis about their origin put forward here. We cannot exclude the possibility that $M$. arvalis also has been introduced. But so far, the only vole species that has been proven to exist in Svalbard is $M$. epiroticus.
Acknowledgements. - This study was supported financially by the Swedish Natural Science Research Council, the Norwegian Polar Research Institute, the 'Fondation Franco-Norvégienne pour la recherche scientifique et technique ct le développement industriel' (FFN) and the Norwegian Research Council for Science and the Humanities (NAVF)

\section{References}

Alendal, E. 1977: Sørlig markmus har fătt fotfcste på Svalbard. Fauna 30, 8-11.

Belanin, A. N., Venig, L. L., Larina, N. I. \& Sonin, K. A 1973: Characteristics of the karyotypes of the comnon vole (Microtus arvalis Pall.) from the Povolžie. Fiziol. popul. ekol. ziv., Saratov 1, 66-72.

Bolshakov, V. N. \& Shubnikova, O. N. 1988: Common vole Microtus arvalis (Rodentia, Muridae) on Spitsbergen archipelago. Zool. Zhurn. 67, 308-310) (in Russian)

Fredga, K. 1987: Chromosome preparations in the ficld from mammals long after death. Stain Technol. 62, 167-171.

Gamperl, R. 1982: Die Chromosomen von Microtus arvalis (Rodentia, Microtinac). Z. Süugetierkunde 47, 356-363.

Hocl, A. 1966: Svalbard 1. Sverre Kildahls Boktrykkeri, Oslo.

Honacki, J. H., Kinman, K. E. \& Koeppl, J. W. (eds.) 1982 : Mammal Species of the World: A Taxonomic and Geographic Reference. Allen Press and The Association of Systematic Collections, Lawrence, Kansas, U.S.A

Král, B., Belanin, A. N., Zima, J., Malygin, V. M., Gajcenko, V. A. \& Orlov, V. N. 1980: Distribution of Microtus arvalis and M. epiroticus. Acta Sc. Nat. Brno 14, 1-30.

Král, B. \& Lyapunova, E. A. 1975: Karyotypes of 46chromosome Microlus arvalis (Microtidac, Rodentia). Zool Listy 24, 1-11.

Malygin, V. M. 1983: Systematics of the common vole. Nauka, Moscow. $208 \mathrm{pp}$ (in Russian).

Malygin, V. M. \& Orlov, V. N. 1974: Areas of 4 species of voles (superspecics Microtus arvalis) by karyological data. Zool Zhurn. 53, 616-622 (in Russian).

Maiygin, V. M. \& Yatserko, V. N. 1986: Taxonomic nomenclature of sibling, species of the common vole (Rodentia, Cricetidac). Zool. Zhurn. 65, 579-591 (in Russian).

Mejer, M. N., Moroz, J. M., Orlov, V. N. \& Scholl, E. D. 1973: Zwillingsarten der Feldmaus, Microtus arvalis (Pallas). Mitt. Zool. Mus. Berlin 49, 387-402.

Mejer, M. N., Orlov, V. N. \& Scholl, E. D. 1972: On the nomenclature of 46- and 54-chromosome voles of the type Microtus arvalis (Pall.) (Rodentia, Cricetidae). Zool Zhurn. $51,157-161$ (in Russian).

Mejer, M. N., Radjabli, S. J., Bulatova, N. S. \& Golenischev, F. N. 1985: Karyotypical peculiarities and probable relations of common voles of the group 'arvalis' (Rodentia, Cricetidac, Microtus). Zool. Zhurn. 64, 417-428 (in Russian).

Niethammer, J. \& Krapp, F. 1982: Microtus arvalis (Pallas, 1779) - Feldmaus. Pp. 284-318 in Niethammer, J. \& Krapp, F. (eds.): Handbuch der Säugetiere Europas 2(1). Rodentia: II. Akademische Verlagsgesellschaft, Wiesbaden.

Nyholm, E. S. 1966: Observations on some birds and mammals of Spitsbergen. Ann. Zool. Fenn. 3, 173-175.

Ride, W. D. L., Sabrosky, C. W., Bernardi, G. \& Melville R. V. (eds.) 1985: International Code of Zoological Nomenclature (3rdedition). International Trust for Zoological 
Nomenclature in association with British Museum (Natural History), London, and Univ. of California Press, Berkeley and Los Angeles.

Ruzic, A., Petrov, B. \& Zivkovic, S. 1975: On the species independence of the 54-chromosome vole Microtus epiroticus Ondrias 1966 (Mammalia, Rodentia), its distribution, ecology and importance as a pest in the west part of Balkan peninsula. J. Sci. Agri. Res. Beograd 28, 153-160.

Sakiyan, S. M., Kulbakina, N. A., Serov, O. L., Mejer, M. N. \& Zharkikh, A. 1984: Assessment of the degree of genetic divergence of the twin species of the common vole Microtus arvalis and Microtus subarvalis (Rodentia). Genetika 20, 1365-1372.
Sumner, A. T. 1972: A simple technique for demonstrating centromeric heterochromatin. Exp. Cell Res. 75, 304-306.

Vorontsov, N. N., Lyapunova, E. A., Belyanin, A. N., Král, B., Frisman, L. V., Ivnitsky, S. B. \& Yanina, I. Y. 1984: Comparative genetic methods of diagnostics and estimation of the degree of divergence for the sibling species of common voles Microtus arvalis and M. epiroticus. Zool. Zhurn. 63, 1555-1566 (in Russian).

Wang, H. C. \& Fedoroff, S. 1972: Banding in human chromosomes treated with trypsin. Nature New Biol. 235 . 52-53.

Zima, J. \& Krâl, B. 1984: Karyotypes of European Mammals II. Acta Sc. Nat. Brno 18, 1-62. 